\title{
VITELLOGENIN AND GLUCOSE CONCENTRATIONS IN THE HEMOLYMPH OF WILD AND CONFINED CRAYFISH (AUSTROPOTAMOBIUS PALLIPES LEREBOULLET 1858)
}

\author{
E. D'AGARO (1), R. METTULIO (2), P.G. GIULIANINI (2)
}

(1) Dipartimento di Scienze della Produzione Animale, Università di Udine, Via s. Mauro 2, 33010 Pagnacco (UD), Italy.

(2) Dipartimento di Biologia, Università di Trieste, Via Giorgieri 7, I-34127 Trieste, Italy.

Reçu en septembre 2003

Accepté le 9 février 2004
Received September, 2003

Accepted February 9, 2004

\begin{abstract}
The white-clawed crayfish (Austropotamobius pallipes) is a native species in the Friuli Venezia Giulia region of North-Eastern Italy. This species is under threat because of habitat modifications and water pollution. Conservation policies are needed and the present study is the first step of a restocking programme. Vitellogenin and glucose concentrations in hemolymph of wild animals and after a period of acclimation were examined. Preliminary results showed no significant differences in high-density lipoprotein subunits in females after acclimation. Glucose hemolymph values are also close to normal levels and similar between males and females. Three types of blood cells were identified in the hemolymph: hyaline cells and small and large granule hemocytes. We conclude that glucose and vitellogenin concentrations in the hemolymph of crayfish were not modified under artificial rearing. Metabolic variables are suitable indicators of crayfish ovarian maturation and environmental and physiological stress.
\end{abstract}

Key-words: Austropotamobius pallipes, vitellogenin, glucose, hemocyte, reproduction.

\section{CONCENTRATION DE VITELLOGÉNINE ET DE GLUCOSE DANS L'HÉMOLYMPHE D'ÉCREVISSE AUSTROPOTAMOBIUS PALLIPES LEREBOULLET 1858 SAUVAGES ET EN CAPTIVITÉ}

\section{RÉSUMÉ}

L'écrevisse à pattes blanches Austropotamobius pallipes est native de la région de Friuli Venezia Giulia dans le Nord-Est de I'Italie. La modification de I'habitat et la pollution mettent en péril cette espèce et des directives pour sa préservation sont désormais nécessaires. Cette étude représente la première étape d'un programme de repeuplement. Les concentrations de vitellogénine et de glucose dans l'hémolymphe des écrevisses ont été déterminées avant et après une période d'acclimatation. Les résultats préliminaires ne démontrent aucune différence significative concernant les sous-unités LHD chez les femelles après acclimatation. Les niveaux de glucose dans l'hémolymphe sont également proches des valeurs normales et sont similaires entre mâles et femelles. Trois types de cellules sanguines ont été identifiés : les cellules hyalines et les hémocytes à petites ou à grandes granules. Les concentrations de glucose et de vitellogénine dans l'hémolymphe 
des écrevisses n'ont pas changé dans les conditions d'élevage artificiel. Les variations métaboliques peuvent être considérées comme des indicateurs de la maturité des ovaires et du stress physiologique ou environnemental.

Mots-clés: Austropotamobius pallipes, vitellogénine, glucose, hémocyte, reproduction.

\section{INTRODUCTION}

The white-clawed crayfish (Austropotamobius pallipes) occurs in several countries in Europe (Ireland, France, Spain, England and Italy). According to GRANDJEAN et al. (2002), the species present in the Friuli Venezia Giulia region should be classified as $A$. italicus carsicus. There is a growing interest in the ecology and biology of this species because of a serious risk of extinction. Nevertheless, there is a paucity of scientific information concerning culture and reproduction of this species and of the effects of environmental factors which occur in captivity and during ovarian maturation. These findings are very important in order to set up breeding techniques and restocking programmes.

The identification of immunological and/or physiological parameters to be used for monitoring the health status and the reproduction phase in cultivated animals is crucial to ensure the success of these programmes. So far, only limited information is available on the physiological and immunological changes induced by captivity, management and environmental stress conditions in crayfish. The circulating hemocytes of crustaceans play an important role in immune responses and they have been proposed as an indicator of stress (JOHANSSON et al., 2000). The number of free hemocytes in the hemolymph can vary in relation to environmental stress and decrease suddenly during an infection (JOHANSSON et al., 2000). Crustaceans have three morphologically different hemocyte types: hyaline, semi granular and granular cells (BAUCHAU, 1980).

In native European crustacean species, the reproduction cycle is very long (69 months) compared to the tropical crayfish species and it occurs only once a year. Crustacean reproduction is regulated by a complex neurohormonal mechanism during the process of oogenesis, previtellogenesis, vitellogenesis and maturation (DE KLEIJN and VAN HERP, 1998). The main objectives of the present study were firstly to check on vitellogenin and glucose concentrations in crayfish if stress induced by captivity could possibly impair reproduction and secondly to identify the types of haemocytes in the white-clawed crayfish for a possible use as a biomarker.

\section{MATERIAL AND METHODS}

The initial stock was made of 15 crayfish (Austropotamobius pallipes) (8 males, average live weight $14.7 \pm 9.93 \mathrm{~g}$ and 7 females, average live weight $13.6 \pm 8.46 \mathrm{~g}$ ). Animals were collected in late autumn by hand catch in wild populations located in the Friuli Venezia Giulia region and transported to the indoor experimental facilities.

Crayfish were held in 200-liter glass tanks in a closed recirculating and aerated system. During the experiment, temperature and photoperiod were kept as much as possible similar to the wild environment $\left(9^{\circ} \mathrm{C}\right.$; L: D 10:14 h). Feed, consisting of a pelleted diet (crude protein, $29 \%$ dry matter and crude fat $8.3 \%$ dry matter), was distributed 6 times per day, by means of automatic feeders at the feeding rate of $1 \%$ of body weight per day. Mortality, moulting, eggs laid and water quality parameters were measured weekly. Hemolymph samples of 100-150 $\mu \mathrm{l}$ were withdrawn from the pericardial sinus of each animal using a 1-ml syringe at the beginning of the experiment and after one month. Each sample was centrifuged for 40 s at $10000 \mathrm{rpm}$ and $50 \mu \mathrm{l}$ of the supernatant was transferred into a tube containing $20 \mu \mathrm{l}$ of anti-protease mixture (Roche diagnostics) and kept on ice. A sub-sample was used for glucose analysis. 
Glucose content was measured using "one touch ® II Meter" (Lifescan) and commercial kit test strips. Separation of HDL from hemolymph was performed on minipolyacrylamide $7.5 \%$ SDS-PAGE (Amersham biosciences). For the SDS-PAGE separation the molecular weight standards of 200, 116, 97, 66, 55, 36, 31, 21 and $14 \mathrm{kDa}$ (RPN 5800, Amersham biosciences) were used. After electrophoresis, gel was silver stained (Amersham biosciences).

The hemocytes were pelleted by $10000 \mathrm{rpm}$ centrifugation for $1 \mathrm{~min}$ and fixed with $2 \%$ glutaraldehyde in $0.1 \mathrm{M}$ cacodylate buffer $\mathrm{pH}$ 7.4. The pellets were then post-fixed in $1 \%$ osmium tetroxide in the same buffer, serially dehydrated in ethanol and embedded, via propylene oxide, in Embed812/Araldite (Electron Microscopy Sciences, Fort Washington, PA). Sections $1 \mu \mathrm{m}$ thick were collected on slides, baked for $5 \mathrm{~min}$ at $80^{\circ} \mathrm{C}$ and stained with $0.5 \%$ toluidine blue in $0.1 \%$ carbonate solution at $\mathrm{pH} 11.1$ at the same temperature.

For light microscopy, sections $2 \mu \mathrm{m}$ thick were collected on slides and baked for $5 \mathrm{~min}$ at $80{ }^{\circ} \mathrm{C}$ and stained with $0.5 \%$ toluidine blue in $0.1 \%$ carbonate solution at $\mathrm{pH} 11.1$ at the same temperature. For the transmission electron microscopy (TEM), silver/gold-coloured sections were collected on 200-mesh nickel grids and stained with uranyl acetate and lead citrate for 5 min each. Sections were observed with a TEM Philips EM 208.

\section{RESULTS}

Animals were all collected in brooks located in the eastern part of the region. The substrate of the brooks was dominated by stones. Brooks were unpolluted and characterized by good water quality. In captivity, all crayfish exhibited apparently normal feeding and good health.

The glucose hemolymph concentrations of $A$. pallipes males and females during the experiment are shown in Figure 1. After capture and one month of confinement, mean glucose levels in the hemolymph of crayfish were close to the normal values and similar between males and females.

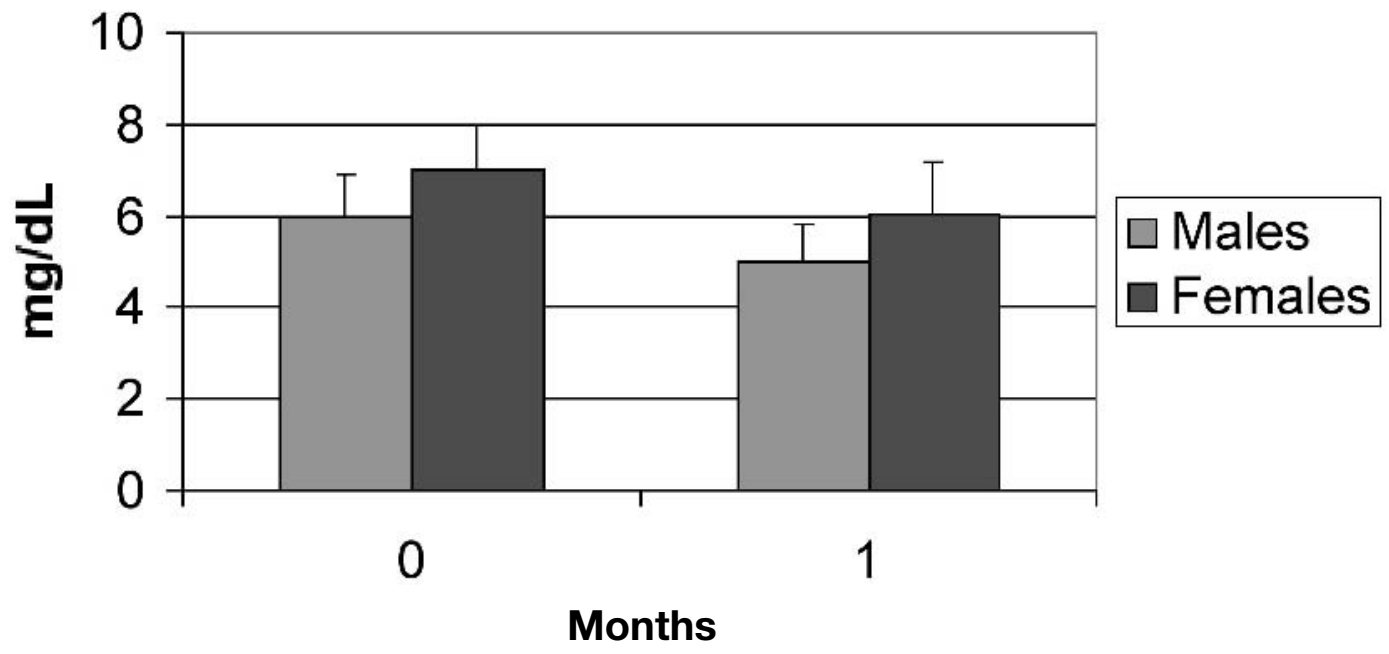

Figure 1

Concentrations de glucose dans l'hémolymphe de $A$. pallipes mâles et femelles au début et à la fin de l'expérience (moyennes de trois mesures).

Figure 1

Glucose concentrations in $A$. pallipes males and females during the experiment (means of three records). 
The $7.5 \%$ SDS-PAGE separation of HDL from hemolymph of A. pallipes females $\left(\mathrm{N}^{\circ}: 1,2,3,4\right)$ at their arrival and after one month of rearing are shown in Figure 2 . The 7.5\% SDS-PAGE separation of HDL from hemolymph showed four subunits with the approximate molecular masses of 143, 180, 190 and $196 \mathrm{kDa}$. Comparing the HDL subunits at the beginning and after one month, no relevant differences were found in any females.

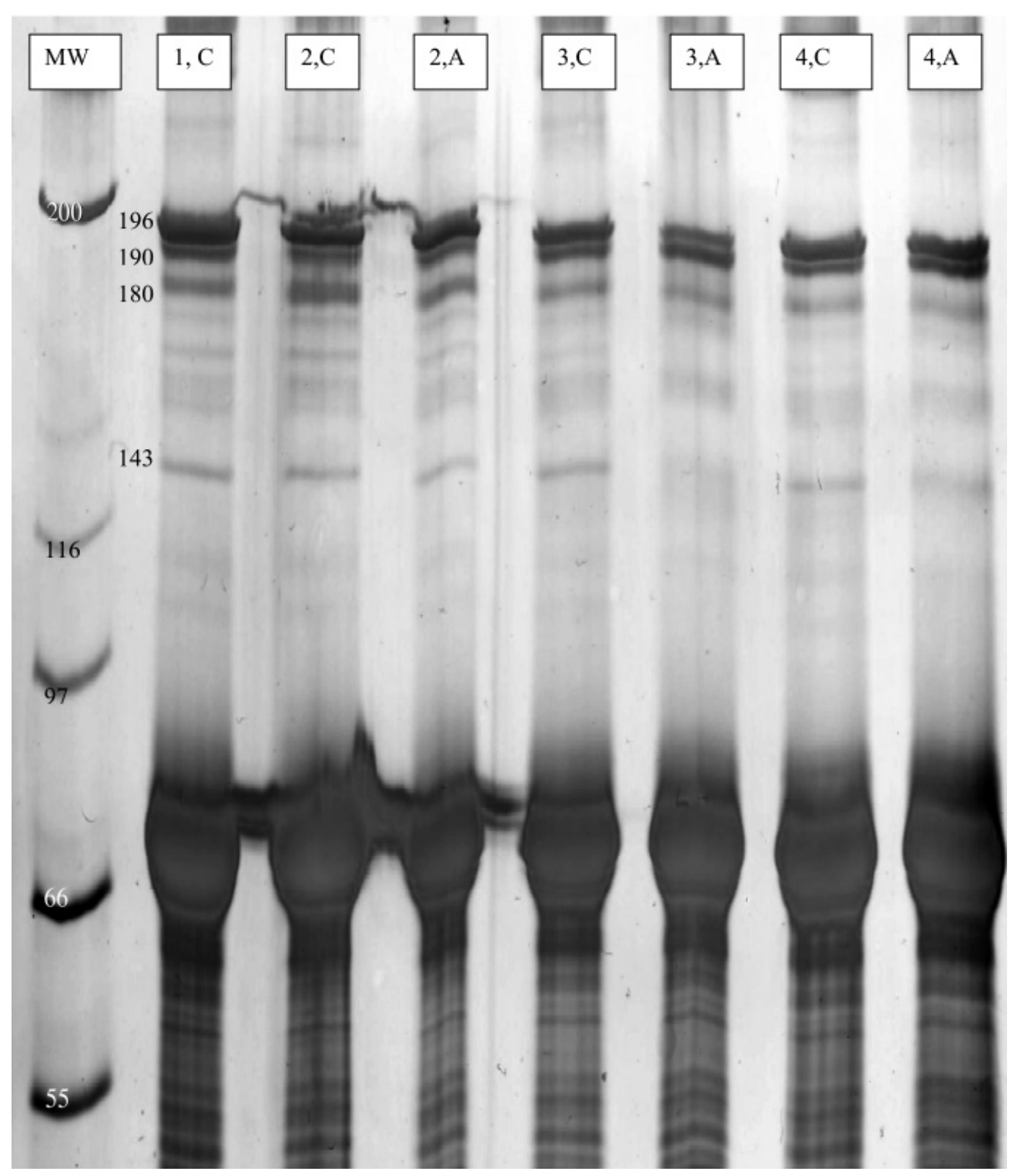

\section{Figure 2}

Séparation 7.5\% SDS-PAGE des LHD de l'hémolymphe de femelles $A$. pallipes $\left(N^{\circ} 1,2,3,4\right)$ pendant l'expérimentation. (C : contrôle, $A$ : après acclimatation).

\section{Figure 2}

7.5\% SDS-PAGE separation of HDL from hemolymph of $A$. pallipes females ( $N^{\circ}: 1$, $2,3,4)$ during the experiment (C: control; A: after acclimatation). 
Three types of blood cells were found in the hemolymph of $A$. pallipes. They were identified as hyaline cells, small granule hemocytes and large granule hemocytes (Figures 3 and 4). These hemocytes are characterized by three different types of cytoplasmic granules that could be identified in toluidine blue stained transverse sections of hemolymph pellets (Figure 3). At the ultrastructural level (Figure 4) the granules types show a maximum diameter of: $1.9 \pm 0.27 \mu \mathrm{m}(\mathrm{n}=20), 0.74 \pm 0.13 \mu \mathrm{m}(\mathrm{n}=20), 0.53 \pm 0.21 \mu \mathrm{m}(\mathrm{n}=20)$ in large granule cells, small granule cells and hyaline cells respectively.

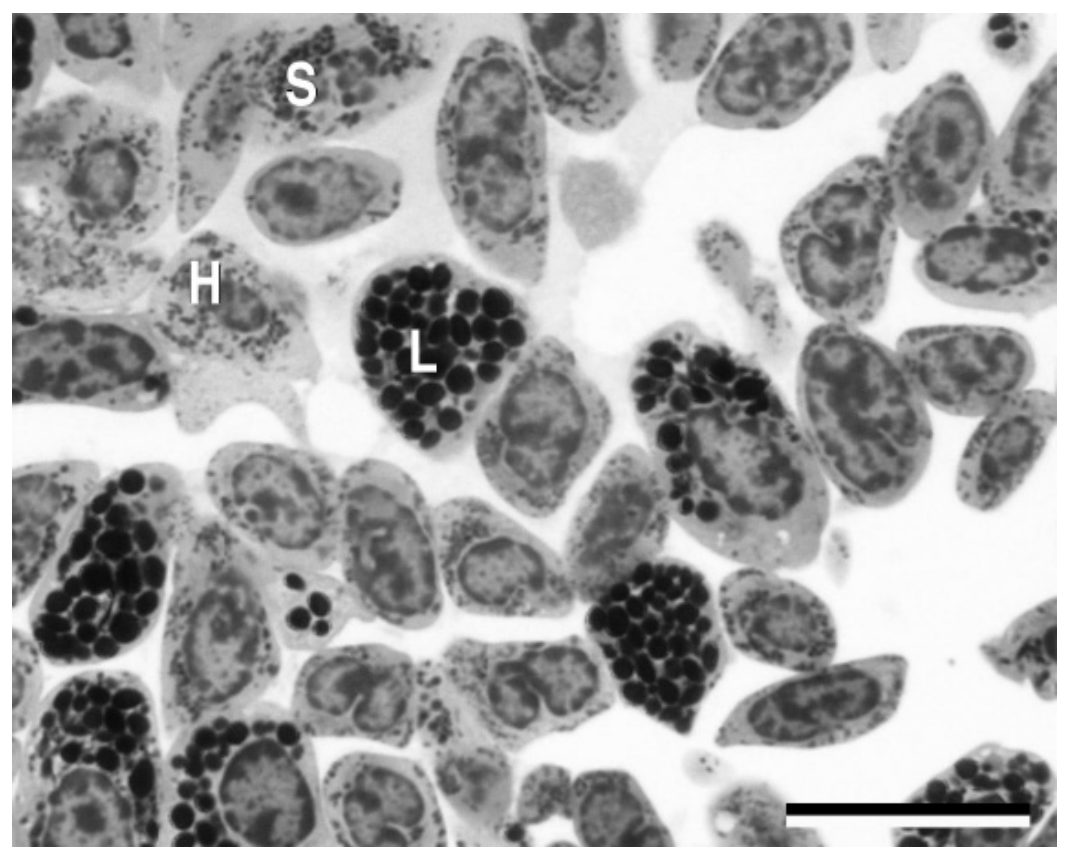

\section{Figure 3}

Sections semi-fines d'un culot d'hémocytes de $A$. pallipes. $\mathrm{H}$ : hémocyte hyaline ; $\mathrm{L}$ : hémocyte à grande granule; $\mathrm{S}$ : hémocyte à petite granule. Échelle : la ligne équivaut à $20 \mu \mathrm{m}$.

\section{Figure 3}

Semithin sections of a pellet of hemocytes of $A$. pallipes. H: Hyaline hemocyte; L: Large granule hemocyte; S: Small granule hemocyte. Scale bar: $20 \mu \mathrm{m}$.

\section{DISCUSSION}

The crayfish $A$. pallipes italicus is a native species in the Friuli Venezia Giulia region. Natural stocks of $A$. pallipes italicus are still abundant and widely distributed in this area. However, several populations show a reduced number and are under threat of extinction mainly because of water pollution and environmental stress. Drought, for instance, which occurred during the summer (2003), was highly detrimental for crayfish causing high mortalities in several rivers. Environmental variations have been shown to induce variations in crayfish metabolism which are often stressful, resulting in a reduction of immune vigour as measured by hemocyte counts (LE MOULLAC and HAFFNER, 2000) or an increase in glucose and total reducing substances (TELFORD, 1968). In the present study, after one month in captivity, glucose concentrations in hemolymph of males and females were not influenced by the environmental change caused by captivity. Hyperglycemia as a secondary stress response has been reported for several species (KUO and YANG, 1999; 

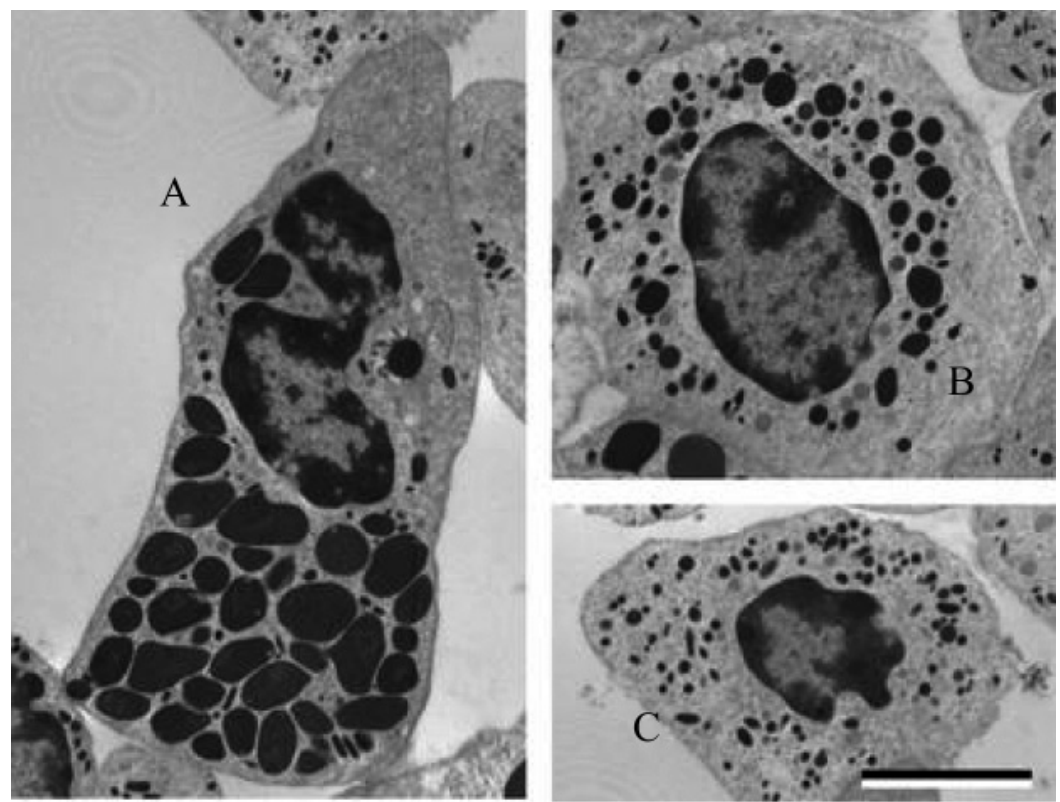

\section{Figure 4}

Ultrastructure des trois types d'hémocytes de $A$. pallipes. $A$ : hémocyte à grande granule, $B$ : hémocyte à petite granule, $\mathrm{C}$ : hémocyte hyaline. Échelle : la ligne équivaut à $10 \mu \mathrm{m}$.

\section{Figure 4}

Ultrastructure of the three hemocytes of $A$. pallipes. A: Large granule hemocyte. B: Small granule hemocyte. C: Hyaline hemocyte. Scale bar: $10 \mu \mathrm{m}$.

LORENZON et al., 1997). Glucose hemolymph levels were in line with concentrations observed in other crayfish species (LANARI et al., 2003).

The isolation, separation and classification of different hemocyte types are based mainly on the presence of cytoplasmatic granules. In the hemolymph of $A$. pallipes were found three different types of hemocytes: hyaline cells, semigranular cells and granular cells. The circulating hemocytes of crustaceans are essential in immunity, performing functions such as phagocytosis and lysis of foreign cells (JOHANSSON et al., 2000). SANCHEZ et al. (2001) used several metabolic variables in Litopenaeus setiferus as indicators of captivity stress. They observed in acclimated shrimp after 7 days in the laboratory a reduction of triacylglycerol, total protein, cholesterol concentrations and total hemocytes in comparison with the base-line shrimp. Similarly, PERAZZOLO et al. (2002) reported in Farfantepenaeus paulensis a reduction of approximately $50 \%$ of the total hemocyte number and total serum protein concentration after exposure to stressful conditions.

Several neuropeptides regulate physiological processes in decapod crustaceans. Among them, $\mathrm{cHH}$ is primarily involved in carbohydrate metabolism (GIULIANINI et al., 2002). Reproductive process in crayfish may be influenced by many environmental variables. Among these, the main biotic factors may be listed temperature, nutrient levels and water quality. Preparation for mating involves not only external morphological changes but also a period of ovary conditioning, during which yolk accumulation (vitellogenesis) takes place within the oocytes (SAGl et al., 1996). The major lipoprotein in the yolk is the vitellin. Vitellogenin is the precursor of egg yolk protein and its concentration is correlated to yolk accumulation in the oocyte. The 7.5\% SDS-PAGE separation of HDL from hemolymph showed four subunits with the approximate molecular masses of 143 , 
180, 190 and $196 \mathrm{kDa}$. ADBU et al. (2001) found in Cherax quadricarinatus six major highdensity lipoprotein subunits $(177,155,106,95,86$ and $75 \mathrm{kDa})$ appearing at different times in the secondary-vitellogenic ovaries. HDL concentrations in hemolymph of females were not influenced after one month in captivity compared to the initial values. Time of appearance and disappearance of the high-density lipoprotein subunits is influenced by environmental factors and the phase of the vitellogenic process.

\section{CONCLUSION}

The pattern observed in the present experiment provides confirmation that the captivity does not physiologically change crayfish. HDL concentrations in hemolymph of females and glucose levels in males and females were not influenced after one month in captivity compared to the initial values. Metabolic variables are suitable indicators of crayfish ovarian maturation and environmental and physiological stress.

\section{REFERENCE}

ABDU U., YEHEZKEL G., WEIL S., ZIVIT T., SAGI A., 2001. Is the unique negatively charged polypeptide of crayfish yolk HDL a component of crustacean vitellin? Journal of Experimental Zoology, 290, 218-226.

BAUCHAU A.G., 1980. Crustaceans. In: RATCLIFFE N.A., ROWILEY A.F. (Eds.), Invertebrate blood cells. Academic Press, New York, 385-420.

GIULIANINI PG., PANDOLFELLI N., LORENZON S., FERRERO E.A., EDOMI P., 2002. An antibody to recombinant crustacean hyperglycaemic hormone of Nephrops norvegicus cross-reacts with neuroendocrine organs of several taxa of malacostracan crustacean. Cell Tissue Research, 307: 243-254.

GRANDJEAN F., FRELON-RAIMOND M., SOUTY-GROSSET C., 2002. Compilation of molecular data for the phylogeny of the genus Austropotamobius : one species or several? Bull. Fr. Pêche Piscic., 367, 671-680.

DE KLEIN D.P.V. and VAN HERP F.V., 1998. Involvement of the hyperglycemic neurohormone family in the control of reproduction in decapod crustaceans. Invertebrate Reproduction and Development, 33, 263-272.

JOHANSSON M.W., KEYSER P., SRITUNYALUCKSANA K., SODERHALL K., 2000. Crustacean hemocytes and haematopoiesis. Aquaculture, 191, 45-52.

KUO C.M. and YANG Y. H., 1999. Hyperglycaemic responses to cold shock in the freshwater giant prawn, Macrobrachium rosenbergii. Journal of Comparative Physiology B, 169, 49-54.

LANARI D., D'AGARO E., FERRERO E.A., CARATI R., LORENZON S., GIULIANINI P.G., 2003. Effects of temperature and photoperiod on glucose and vitellogenin hemolymph concentrations in crayfish Cherax quadricarinatus (van Martens 1868). Italian Journal of Animal Science, Vol. 2 (Suppl. 1), 634-636.

LE MOULLAC G. and HAFFNER P., 2000. Environmental factors affecting immune responses in Crustacea. Aquaculture, 191, 121-131.

LORENZON S., GIULIANINI P.G., FERRERO E.A., 1997. Lipopolysaccharide-induced hyperglycaemia is mediated by $\mathrm{CHH}$ release in crustaceans. General and Comparative Endocrinolology, 108, 395-405. 
PERAZZOLO L.M., GARGIONI R., OGLIARI P., BARRACCO M.A.A., 2002. Evaluation of some hemato-immunological parameters in the shrimp Farfantepenaeus paulensis submitted to environmental and physiological stress. Aquaculture, 214, 19-33.

SAGI A., SHOUKRUN R., KHALAILA I., RISE M., 1996. Gonad maturation, morphological and physiological changes during the first reproductive cycle of crayfish Cherax quadricarinatus female. Invertebrate Reproduction and Development, 29, 235242.

SANCHEZ A., PASCUL C., SANCHEZ A., VARGAS-ALBORES F., LE MOULLAC G., ROSAS C., 2001. Hemolymph metabolic variables and immune response in Litopenaeus setiferus adult males: the effect of acclimation. Aquaculture, 198, 13-28.

TELFORD M., 1968. The effects of stress on blood sugar composition of the lobster, Homarus americanus. Canadian Journal of Zoology, 46, 819-826. 